\title{
INDONESIAN CELEBRITIES CONVERSION: THE QUEST FOR MEANING AND SOCIAL ENVIRONMENT ${ }^{1}$
}

\author{
Gazi Saloom \\ Syarif Hidayatullah State Islamic University, Jakarta \\ Email: gazi@uinjkt.ac.id
}

\begin{abstract}
Religious conversion has often triggered a heated debate that pushes forward scholarly investigation. This paper is not based on a theological study of conversion, but a psycho-social exploration that aims to examine religious conversion among Indonesian celebrities and seeks factors that influence the conversion. This qualitative study selects five Indonesian celebrities who converted to Islam. All data and information were gathered from YouTube and the websites on entertainment and celebrity news. The study unveils that religious conversion is not a simple one-way process. Instead, it is a long process of search of meaning and identity, shaped by interpersonal relations and social interactions. Before conversion, the converts had made personal and colleague relationship with their Muslim friends and known Islam as it was manifested in everyday life through TV program, the call for Islamic prayer (adhān), neighborhood. The fact that Islam is the majority religion in the country has provided environments that further hastened the quest for the meaning of religion and identity amongst the celebrities.
\end{abstract}

Keywords: Religious conversion, celebrities, meaning, social environment

DOI: https://doi.org/10.20414/ujis.v23i2.344

\section{Introduction}

SOME EXPERTS NOTED that social and personal changes are hardly deniable for every individual because people are not living in solitude but in a context where they face various issues that

1 This article is originally based on my research report on religious conversion that was funded by Jakarta State Islamic University Research Center. 
eventually lead them to experience individual transformation. ${ }^{2}$ There are many ways of transformation that individuals may experience including spiritual transformation or religious conversion. The religious conversion is not an uncommon phenomenon since it can happen to everyone both laypeople and celebrities.

Religious conversion has been discussed by many experts from various fields, including psychology, particularly in the psychology of religion. ${ }^{3}$ The modern academic study of the psychology of religious conversion could be traced back to the end of the eighteenth century when Stanley Hall delivered his lecture on religious conversion in the Christian context. To some extent, William James, the father of the psychology of religion, has also talked more about this phenomena in his series of lectures on varieties of religious experiences. ${ }^{4}$

Another researcher who studied religious conversion was Prince. He discussed the phenomena of religious conversion from William James's perspective. In his article, Prince said that unforeseen religious conversion was related strongly to people's subconscious. In the Freudian perspective, the subconscious play an essential role in such process ${ }^{5}$ although it was apparent how this concept works in the context of religious conversion.

Religious conversion has usually been related to personal factors and social factors. Gooren, for example, found that there are three factors that have strongly impacted religious conversion. These are personal factors, organizational factors and socialcultural factors that pushed individuals to leave their religion and embrace a new one. ${ }^{6}$

${ }^{2}$ Geoffrey Lawrence Cohen and David Sherman, The Psychology of Change: Self-Affirmation and Social Psychological Intervention, SSRN, 2014.

${ }_{3}$ Charles E. Farhadian, Christianity, Islam and Nationalism in Indonesia, Christianity, Islam and Nationalism in Indonesia, 2005.

${ }^{4}$ Duane F Reinert and John R Bloomingdale, "Religious Experiences (Argyle 2000) PDF," International Journal for the Psychology of Religion (2000).

${ }^{5}$ M Prince, "The Psychology of Sudden Religious Conversion," Journal of Abnormal Psychology (1906).

${ }^{6}$ Henri Gooren, Religious Conversion and Disaffiliation: Tracing Patterns of Change in Faith Practices, Religious Conversion and Disaffiliation: Tracing Patterns of Change in Faith Practices, 2010. 
It is interesting to note that there are debates about the effects of religious conversion toward personality changes. Does religious conversion give impacts on personality change? Some studies argue that conversion influence personality changes. Other studies maintain that conversion does not change personality. This present study, however, agrees to the third view stating that conversion sometimes influences personality change but not

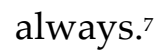

The fundamental reason for such contestation is due to different theoretical perspective and data on religious conversion. There are a number of studies on religious conversion in Indonesia. ${ }^{8}$ However, most of them do not particularly examine the conversion amongst Indonesian celebrities. Therefore, studying and writing about religious conversion are still needed in order to enrich the current state of the literature on religion and personal transformation in Indonesia.

Conversion is a global phenomenon. A report shows that a number of people converting to Islam are steadily rising. ${ }^{9}$ In Indonesia, this holds true. A number of ordinary Indonesians in recent years have converted to Islam. Moreover, such conversion has occurred among public figures such as celebrities. The news of their conversion spread quickly and widely through television and social media.

7 Raymond R Paloutzian, James T. Richardson, and Lewis R. Rambo, "Religious Conversion and Personality Change," Journal of Personality (1999); Chana Ullman, "The Transformed Self: The Psychology of Religious Conversion.," The Transformed Self: The Psychology of Religious Conversion., 1989.

${ }^{8}$ Haedar Nasir and Mutohharun Jinan, "Re-Islamisation: The Conversion of Subculture from Abangan IntoSantri in Surakarta," Indonesian Journal of Islam and Muslim Societies (2018); Myengkyo Seo, "Falling in Love Changing Gods: InterReligious Marriage and Religious Conversion in Java, Indonesia," Indonesia and the Malay World (2013). See Also Christopher R. Duncan, "Untangling Conversion: Religious Change and Identity among the Forest Tobelo of Indonesia," Ethnology 42, no. 4 (2003): 307-322; Intan Paramaditha, "Passing and Conversion Narratives: Ayat-Ayat Cinta and Muslim Performativity in Contemporary Indonesia," Asian Cinema 21, no. 2 (2010): 69-90.

${ }^{9}$ Robert M. Carrothers, "Social Typing of Religious Changers: The Impact of Motivation on the Stories of Alternators and Converts," Sociological Spectrum 27, no. 2 (March 2007): 133-150. 
Many fans certainly like this decision on one hand, but on the other hand, there are many fans also who dislike it. The comments of those who like and of those who dislike indicated that celebrities have a particular position and role in public. In general, whatever they are doing will influence the public, especially when this deals with religion as it is a very sensitive issue in this country.

Many Indonesian celebrities are reported to have converted to Islam, such as Chicha Koeswoyo, Angelina Sondackh, Dian Sastro Wardoyo, Dewi Sandra, Tamara Bleszynski, Marsha Timothy, Merry Goeslow, Berry Saint Loco, RD and others. ${ }^{10}$ Their decision to embrace Islam surprised the public, mainly their non-Muslim fans, and the other Muslim fans who were happy to know this reality. This situation certainly creates some issues and concerns that need to be discussed.

What do psychologists suggest about religious conversion? There are certainly some studies scrutinizing about this phenomenon. For example, Snow and Machalek suggested that religious conversion was related to radical personal change. In other words, radical personal change cognitively and affectively in some cases caused individuals to decide to convert new ideology or new religion ${ }^{11}$.

Garfinkel also has studied about personal transformation that related to violence and peace. Garfinkel reported about two outstanding figures among Muslim communities and Christian communities who transformed from radical cleric to peaceful cleric. Garfinkel asserted that social factor opens mindedness and initiative to make contact with individuals from other groups that

${ }^{10}$ News and information about those who convert to Islam can be found in many sources of internet, such as Editors, "Sebelum Roger Danuarta, 10 Artis Ini Lebih Dulu Jadi Mualaf," JPNN.COM, last modified 2018, msn.com/idid/hiburan/celebrity/sebelum-roger-danuarta-10-artis-ini-lebih-dulu-jadimualaf/ar-BBP93hw. See also Amrikh Palupi, "5 Artis Yang Telah Lebih Dahulu Mualaf Sebelum Roger Danuarta," DREAM.CO.ID, last modified 2018, https:/www.dream.co.id/showbiz/sebelum-roger-danuarta-5-artis-inimemutuskan-memeluk-islam-181030d.html.

11 Carrothers, "Social Typing of Religious Changers: The Impact of Motivation on the Stories of Alternators and Converts." 
have given them new information and knowledge about kindness and positive sides of the others. ${ }^{12}$

The most pivotal point I stressed from Machalek's and Garfinkel's arguments is that religious conversions or spiritual transformations are inseparable from individual and social psychological dynamics. This point actually has been stated by previous experts in psychology and could be found in many kinds of literature and books of behavioural sciences.

In the context of conversion and religious behavioural transformation, it can be said that personal changes, including religious conversion, would contribute to social changes in general. Muslim scholars, such as Quraish Shihab, insisted that personal change is the basis of social change. He cited some verse from the Qur'an that deals with it. The main point of the verses is that Allah never changes the condition of the people before they change their psychological dimensions. In the perspective of the psychologists, the dimension of the psychology consists of cognition or thought affection or feeling and behaviour. He further stressed the cognition such as cognitive style as a fundamental of the change and transformation at an individual level. It means that without cognitive change, the personal change is impossible to shift, and without personal change, it is possible for social change to happen. ${ }^{13}$

Some other studies about personal changes have been conducted by, for example, Moghaddam. He studied about how ordinary persons transformed into radical and even terrorists. According to him, some persons can become radical through various steps that he called "stairs to terrorism". These steps begin from personal psychological problems that every individual of us face in our daily life and end into terrorist networks that they cannot escape. ${ }^{14}$ There are, of course, some steps between this first step and last steps of pivotal processes in which individuals made

12 Renee Garfinkel, "Personal Transformations: Moving from Violence to Peace" (2007): 1-16.

${ }^{13}$ MQ Shihab, "Membumikan Al-Quran: Fungsi Dan Peran Wahyu Dalam Kehidupan Masyarakat," Bandung: Mizan (1992).

${ }^{14}$ Fathali M. Moghaddam, "The Staircase to Terrorism: A Psychological Exploration.," American Psychologist 60, no. 2 (2005): 161-169. 
to be radicals and in turn to be terrorists. The most important processes were indoctrination in which some ideologies penetrated into their cognition that can change them into a new personality. ${ }^{15}$

Therefore, religious conversions as a part of personal change influenced social and even political changes. Based on this, it can be said that the study of religious conversion is something important in the academic field including of course social science, such as social psychology in general and psychology of religion in particular. It can be said that studying religious conversion among Indonesia celebrities would be more important than merely studying religious conversion in other population. It is because Indonesian celebrities like other celebrities in many countries have significant impacts and contributions to the lifestyle of the public.

To strengthen the background of this article, $t$ must be noted that there are many studies which have been conducted on religious conversion among celebrities, for example, Lofton ${ }^{16}$ and Setiawan Rani. ${ }^{17}$ Nevertheless, a few studies on the Indonesian celebrities have been carried out ${ }^{18}$ even though religious conversion among Indonesian celebrities is an important issue that must be studied in order to develop theories on religious conversion and celebrities. Besides, it must be noted that there are many things uncovered about psychological dynamics related to the quest for significance among limited groups, such as celebrities.

Quest for significance is a pivotal factor that pushes and pulls people to behave, including those related to religious conversion. It was predicted that the quest for significance could explain why

${ }^{15}$ Freddy A Paniagua, "From the Terrorists' Point of View: What They Experience and Why They Come to Destroy," Journal of Homeland Security and Emergency Management 3, no. 4 (2006): 10.

${ }^{16}$ Kathryn Lofton, "Religion and the American Celebrity," Social Compass 58, no. 3 (September 2011): 346-352.

17 Jenny Lukito; Dwisaptani Setiawan Rani, “Konversi Agama Dalam Kehidupan Pernikahan," Jurnal Humaniora (2008).

${ }_{18}$ M. Slavkova, "Gypsies in Lom: The Case of the Gypsies Who Convert to Protestant Christianity," in Religious Conversion After Socialism, 2005; Setiawan Rani, “Konversi Agama Dalam Kehidupan Pernikahan.” 
people convert to a religion or religious movement. Quest for significance is pivotal for human beings in their life, and it can be said that religion is one of the primary sources for people to find meanings. ${ }^{19}$ In every civilization or culture, religion or some kinds of religion have a prominent role in life, including in Indonesia. ${ }^{20}$

Process of the quest for significance will not go well without supporting others in the social surrounding because the others have been playing an important role in the long history of the human being. In the absence of the other people in the surrounding, it is impossible for individuals to live significantly. ${ }^{21}$ Feeling as significant or meaningful individuals can complete their existence as part of the social network or community. ${ }^{22}$ Therefore, the quest for significance should work in the context of the social network in our life, and these two things are inseparable parts that are always related to each other. ${ }^{23}$

However, in this context, the role of the narrative cannot be ignored. The narrative has impacts on the process of the quest for significance and development of the network, and certainly in the interaction between the two factors. Then, to some extent, the role of the quest for significance, the narrative and the network can explain the reason why religious conversion happens.

Based on the above description, this article will explore the phenomena of the religious conversion among Indonesian celebrities and examine them from the perspective of the psychology of religion and, in particular, from the perspective of social psychology. The perspective of N3 theory (need of

${ }^{19}$ Kioulos K.T. et al., "Religiosity Dimensions and Subjective Health Status in Greek Students," Psychiatrike = Psychiatriki (2015).

${ }^{20}$ Rodney D. Coates, "Introduction: Critical Racial and Ethnic Studies Profiling and Reparations," American Behavioral Scientist 47, no. 7 (2004): 873-878.

${ }^{21}$ Orrin Devinsky and George Lai, "Spirituality and Religion in Epilepsy," Epilepsy and Behavior, 2008.

${ }^{22}$ MF Steger, S Oishi, and S Kesebir, "Is a Life without Meaning Satisfying? The Moderating Role of the Search for Meaning in Satisfaction with Life Judgements," The Journal of Positive Psychology 6, no. 3 (2011): 173-180.

${ }^{23}$ C David Gartrell and Zane K Shannon, "Contacts, Cognitions, and Conversion: A Rational Choice Approach," Review of Religious Research Religious Research Association, Inc. Review of Religious Research (1985). 
significance, narrative and network) from Kruglanski ${ }^{24}$ will be used to understand and to explain this phenomenon.

In relation to this phenomenon of religious conversion and N3, some questions have been constructed to be discussed in the article. First, how does religious conversion occur among Indonesian celebrities? Second, what are factors that influence such conversion?

This article is a part of the study that used qualitative method by reviewing media, including social media, such as YouTube as a source of data. The data was analysed by using a thematic analysis technique. All information and data particularly related to religious conversion, was transcribed and analysed through several steps that used to use in the qualitative study. Five Indonesian celebrities were chosen to be subjects purposively. All of them experienced a conversion to Islam. It means that their processes in pursuing hidāya (divine guidance) will be deeply studied and analysed in order to find a theory that depicted it.

In order to find some concepts or constructs related to the research, news and statements of the subjects have listened infrequent times. The concepts or the constructs found in the statements were written and reduced, and then any relation or correlation among the concepts and the constructs are built.

Conceptualization mechanism of the data and information related to the goal of the study was an effort to depict the processes of the religious conversion that occurs among Indonesian celebrities. It also can be the identification of some factors that push individuals to convert religiously and then transformed themselves to be new individuals or personals who were different from their old personality. Finally, this research article tried to establish some new little theory that explained psychological and social mechanisms that went on among celebrities. It is certainly obvious that this proposed theory does not mean that it can be comprehensively explained and can be generalized into all events and experiences experienced by all.

${ }^{24}$ Arie W. Kruglanski and Edward Orehek, "The Role of the Quest for Personal Significance in Motivating Terrorism," The Psychology of Social Conflict and Aggression (2011): 153-164. 
Findings of this research will be managed on the basis of thematic analysis, as explained in many kinds of the literature of qualitative methods. All themes are established through qualitative analysis, steps and processes.

\section{Table 1}

Subjects of the study and their short description

\begin{tabular}{|c|c|c|}
\hline No. & $\begin{array}{l}\text { The } \\
\text { Celebrities } \\
\text { Names }\end{array}$ & Short Description \\
\hline 1 & CK & $\begin{array}{l}\text { This senior artist and vocalist who was popular } \\
\text { in the } 80^{\text {th }} \text { and } 90^{\text {th }} \text { was Protestant and decided } \\
\text { to become Muslim when she was } 16 \text { years old. } .^{25}\end{array}$ \\
\hline 2 & DSW & $\begin{array}{l}\text { DSW is well known as a talented actress since } \\
\text { she played in the film "Pasir Berbisik" } 2001 \text { and } \\
\text { "Ada Apa Dengan Cinta" 2002. She decided to } \\
\text { convert to Islam in 2006. }{ }^{26}\end{array}$ \\
\hline 3 & RK & $\begin{array}{l}\text { She is a model and a popular film star. She } \\
\text { initially began her career as a model in clip } \\
\text { video and played in the film with the title } \\
\text { "Nazar". RK converted to Islam in } 2014 \text {. }\end{array}$ \\
\hline 4 & AN & $\begin{array}{l}\text { She is an Indonesian model and actress. She } \\
\text { decided to be Muslimah in } 2007 \text { after involving } \\
\text { in the film "Ketika Cinta Bertasbih." }\end{array}$ \\
\hline 5 & $\mathrm{RD}$ & $\begin{array}{l}\text { This popular actor decided to become Muslim } \\
\text { in October 2018, and he declared to accept Islam } \\
\text { in front of the senior Muslim preacher Insan } \\
\text { Mokoginta and Steven. }\end{array}$ \\
\hline
\end{tabular}

\section{Pathways of Religious Conversion}

Religious conversion is long processes that happen among individuals seeking the meaning of life. As mentioned in some kinds of literature, ${ }^{27}$ a quest for significance or the meaning of life

${ }^{25} \mathrm{https} / / / \mathrm{www} . v i v a . c o . i d /$ siapa/read/908-chicha-koeswoyo See also YouTube Channel https://www.youtube.com/watch?v=r2cY0RW4Nu4

${ }^{26}$ https://id.wikipedia.org/wiki/Pasir_Berbisik

${ }^{27}$ Kate Miriam Loewenthal, "Psychological Perspectives on Religion and Religiosity," Mental Health, Religion \& Culture (2015). 
is a behavioural phenomenon that happens in every individual in our daily life. It is because every person should encounter many barriers and obstacles in individual life and social realm. ${ }^{28}$ In the psychological perspective, this process is called "an identity crisis" in which everyone should ask him/herself and what can he/she do for others. This existential question pushes him/her to seek for the meaning of life, including through spiritual and religious way. ${ }^{29}$

Identity crisis is not merely related to a big idea or big problem but also related to a simple thing, such as interpersonal relationship or lacks of friends in daily life. ${ }^{30}$ This lack of friends contributes to loneliness and in turn, pushes the individual to the crisis, in particular, that related to identity as human and to effort to seek meanings as a social being. However, it must be noted that having many friends has also contributed to identity crisis and effort to the quest of meaning. Usually, this can be clearly explained with social learning theory. ${ }^{31}$ In this perspective, any individual can learn many things such as regularity from the surroundings, friends and social network. ${ }^{32}$ In this context, there are many examples of the convert of religion who decide to change their religious beliefs because of the observation and experience in social relationships with other religious members. ${ }^{33}$

In some cases, a single personal event can trigger a long process of religious conversion. This may even lead to a point of decision making to enter new spiritual experiences and eventually

${ }^{28}$ Lillian Rayburn, Carole A., and Comas-Dias, “Woman Soul: The Inner Life of Women's Spirituality Edited by Carole A. Rayburn and Lillian Comas-Diaz," American Psychological Association 20, no. 2 (2008): 148-149.

29 A. R Rajaei, "Religious Cognitive-Emotional Therapy: A New Form of Psychotherapy.," Iranian journal of psychiatry (2010).

${ }^{30}$ Karin van Nieuwkerk, "Conversion" to Islam and the Construction of a Pious Self," The Oxford Handbook of Religious Conversion (2014).

31 Kelly G Shaver, "Principles of Social Psychology," Principles of Social Psychology (1987).

32 Albert Bandura et al., "Social Cognitive Theory: An Agentic Perspective," Annual Review of Psychology 55, no. 1 (2004): 1-23.

${ }_{33}$ Pierre-Yves Brandt, "Religious Conversion: A Creative Process.," Archives de Psychologie (2005). 
to be a new individual. ${ }^{34}$ For example, Chicha Koeswoyo, a senior Indonesian artist and the most popular singer in the 1990s, experienced a simple personal event that pushed her to convert to Islam. As she said in many internet webs, she hated Islam, particularly Islamic prayer call ( $a d h \bar{a} n)$ because the call was noisy and troublesome in the dawn prayer. Furthermore, she always turned off television when it broadcasted the call of Islamic prayer. But once upon a time, she felt new experience about the call for prayer that she used to hate. In that time, she actively enjoyed the voice of the call for prayer and was eager to know more about it. ${ }^{35}$

Then, she learnt about Islam and the call for prayer, from which she started learning and performing Islamic prayer. She read many books about Islam and searched for further information from TV and radio programs on Islam. She finally tried to perform the prayer regularly five times a day as Muslims do. She found convenience and soft heart after doing the prayers either in the home or outside the home, openly or secretly. With such spiritual experiences, she concluded that Islam was the true religion from the true God. ${ }^{36}$

In the first time, her mother was distraught to know that her daughter converted to Islam. They did not talk to each other for a while. They then attempted to seek a solution and consulted with a female Muslim preacher and scholar, Zakiyah Darajat, who suggested the mother let her sister go with her decision. Everyone accepted the advice and the mother was willing to accept her daughter's decision. She warned her to be serious with her new faith. She wanted her daughter to be a good religious Muslim like her grandfather, who was also a Muslim. However, in her mother's opinion, the most important reason why she eventually endorsed her daughter's decision was that she converted to Islam

${ }^{34}$ Lewis R. Rambo, "Conversion: Toward a Holistic Model of Religious Change," Pastoral Psychology (1989).

35 https://www.youtube.com/watch?v=nweVqH4LmT0 See also https://swararakyat.com/sedih-kisah-mualaf-chicha-koeswoyo-mamakuperempuan-luar-biasa

${ }^{36}$ https://www.viva.co.id/siapa/read/908-chicha-koeswoyo 
independently through a long process of seeking a meaning of life. ${ }^{37}$

Another covert of the famous figure is DSW, who was a Christian and decided to become a Muslim in 2006. She explained her reason for the conversion was because she was attracted to Islamic teachings and values. Therefore, she was actively eager to deepen her interest in studying Islam independently in order to solve questions that she had regarding divine spirituality.

DSW curiosity to look for the truth particularly related to religiosity was inherited from his father. Mr. Sastro was well known as a person with a strong impetus to seek the truth of religion that can guarantee his calmness and happiness. This tendency and critical trait were inherited his daughter, DSW. In her beginning of adolescence, she was interested in learning many religions, such as Buddha, Hindu, Confucian, Christian, Catholic and Islam. Eventually, after a long journey of search, she found that Islam offered her answer she was looking for. This, in turn, helped facilitate her conversion to this religion. She found a teacher who could explain to her about Islamic spirituality and other aspects of it. She publicly declared to convert into Islam in the night of Isra $\bar{a}^{\prime} M i^{\prime} r \bar{a} j$ (one of the Islamic holidays to commemorate the spiritual journey of the Prophet Muhammad to receive the commandment of prayer from God) in 2004. Her decision could make a fantastic move since she disliked Islam, which she considered as the religion of violence and war. ${ }^{38}$

In relation to DSW case, it can be said that interaction between personal and social factors play a pivotal role in bringing somebody to interact with a new environment or experience. Despite a long process of making sense with Islam, she actually lived in a community where Muslims were the majority. Islam was not totally alien to her. She had many Muslim friends and used to play with them. In addition, as she acknowledged, her parents gave her the freedom to learn and know any interesting object,

${ }^{37}$ https://id.wikipedia.org/wiki/Chicha_Koeswoyo

38 https://feed.merdeka.com/story/perjalanan-spiritual-dian-sastro-memilihmemeluk-agama-islam-170605j.html. See also https://www.youtube.com/watch? $\mathrm{v}=\mathrm{V} 9 \mathrm{M} 1 \mathrm{YIB7c3c}$ 
including religion if it was of interest to her. Therefore, before studying Islam deeply, she had studied many other religions and came to a conclusion to accept Islam. ${ }^{39}$

DSW criticism was a result of high discipline in her family. It was her mother that shaped a lot her criticism. She acknowledged that her mother compelled her to finish reading one book every month and review its content. This condition and habit influenced her character since childhood that contributed to DSW curiosity in seeking for the truth of religion. Her decision to convert thus cannot be separated from both factor: social-environment and personal-family influences. ${ }^{40}$

The third figure converting to Islam that this paper discusses is RK. She decided to convert to Islam one month before getting married to Fachri Albar on May 6, 2014, in Sunda Kelapa Mosque, South Jakarta. Her decision to adhere to Islam raises a heated debate among the public. Some accused of her as having a hidden agenda to convert, that is to marry a Muslim man. Other comments just stated that the decision is not unusual, and she had a right to decide her won religion. ${ }^{41}$ Conversion for the sake of marriage is very common since the marriage law in Indonesia require a couple holds the same religion before they marry.

RK was a Catholic woman with strong religious teaching in her family. According to some news sources, RK's decision to convert to Islam prior to her marriage was because Fachri's family would only support the marriage if RK was a Muslim. The family maintained that it was a complicated matter when RK held different faith while Albar was a Muslim. Most Muslim scholars restrict Muslims to marry to non-Muslims. However, according to RK, she accepted Islam not only because of marriage but also of her curiosity to learn Islam seriously. She further insisted that she

39 https://feed.merdeka.com/story/perjalanan-spiritual-dian-sastro-memilihmemeluk-agama-islam-170605j.html See also https://www.youtube.com/watch? $\mathrm{v}=\mathrm{LAFbccty} 36 \mathrm{E}$

40 https://www.matamata.com/seleb/2018/07/10/083304/7-artis-dengankecerdasan-luar-biasa.

$41 \quad$ https://m.merdeka.com/piala-dunia/calon-istri-fachri-albar-renatakusmanto-sudah-mualaf.html See also https://www.youtube.com/watch? $\mathrm{v}=\mathrm{Ttv} 2 \mathrm{ngXycuc}$ 
knew Islam when she was a student in the elementary school where she had many Muslim friends. ${ }^{42}$

RK's intense study of Islam came only after the marriage, where she learnt from her husband and his family. Albar's family was a religious and committed Muslim and was knowledgeable enough about Islam. RK started reading the Qur'an under the guidance of her mother-in-law. She also studied basic knowledge and tenets of Islam from her, such as prayer five times every day and fasting in Ramadhan. RK's experiences in performing Islamic ritual such as fasting in Ramadhan was widely broadcasted in mass media and newspapers. To her, as a Muslim convert and young mother with a baby, fasting at the first time created a special feeling for her. On the one hand, she could not eat and drink in the day because these would nullify the fasting but, on the other hand, she had to feed her new baby. She kept doing both and did not escape from the fasting because it was hard to fast on the other days. Doing these two jobs in one time created a particular impression to her that she had never felt in the past. ${ }^{43}$

The other Muslim-convert is AN, who is well-known after her involvement as one of the main stars in a popular Islamic movie Ayat-ayat Cinta (Verses of Love), based on a novel written by a graduate of al-Azhar University, Cairo and a gifted novelist Habiburrahman al-Syirazi. This actress decided to convert as Muslimah in 2007. She also played the main figure in other Islamic-popular movies Ketika Cinta Bertasbih (When Love is Chanting). Some said that she was attracted by the way her Muslim friends perform Islamic commandments but can still manage their time between daily rituals such as praying five times a daily and conducting their tasks as actress and actors. AN saw that her Muslim colleagues were committed to their religion and enjoyed their lives happily. This force gave a profound impact on her life that drove her to convert to Islam. ${ }^{44}$

42 https://www.liputan6.com/showbiz/read/2271457/mualaf-renata-kusman to-belajar-agama-dengan-mertua See also https://www.youtube.com/watch? $\mathrm{v}=\mathrm{Tf} X j \mathrm{jgOXx3IQ}$

${ }^{43}$ https://www.tabloidbintang.com/berita/polah/read/23859/ini-cerita-renatakusmanto-nikmati-bulan-ramadhan-kedua

${ }^{44}$ https://id.wikipedia.org/wiki/Alice_Norin 
As a popular actor, RD is well known among Indonesian people, mainly those categorized as the millennial generation. He has played like a star movie and main figure in many films with youth themes, including action films. He told people in YouTube that most of his friends were Muslims and very religious in their daily life. He also said that they were very kind and so polite that he was interested in making close interaction with them. He felt convenient to present with them because he got homage from the surroundings. 45

RD's grandfather was a Muslim from Cirebon, a coastal town in West Java with a famous Islamic kingdom as the centre of Islamic mission and propagation in the past. He, therefore, was accustomed to knowing Islam from an early age. He spent his childhood in Malaysia, and when he grew up, he moved to Jakarta. In this city, he began to tie a close relationship with female actresses such as Sandi Aulia and Marcelia. He was even about to get married to one of them. However, his family, especially his father, refused to support his intention to marry. Another factor that he never imagined happening in his life further had complicated and ruined his planning. ${ }^{46}$

Later on, RD openly announced that he converted to Islam, a decision that sparked speculation and curiosity in the world of Indonesian stars about his changing life. They were eager to know the reason for his conversion. His colleagues, such as Ustadh Steven, the chief of Muallaf Centre Jakarta, asserted that RD's decision was purely based on his own will. To him, RD had been interested in Islam since many years ago. Three years prior to his conversion, he made an intensive interaction and dialogue with his Muslim colleagues. He got an excellent impression of Islam, especially its teaching on self-management. He observed that Islam teaches discipline and respectful of time, as this can be seen from his committed Muslim friends in managing their time to worship and work. ${ }^{47}$

${ }^{45}$ https://www.viva.co.id/siapa/read/981-roger-danuarta

46 https://www.viva.co.id/showbiz/gosip/1107702-bikin-haru-roger-danuar ta-beberkan-alasannya-masuk-islam. Look at also channel YouTube, https://www.youtube.com/watch?v=9AbC_RihnpY

${ }^{47}$ https://www.youtube.com/watch?v=3vIQj3rD4y8 
Notably, he was impressed by Islam when he spent his time with his Muslim colleagues in Ramadhan where they were fasting during the day. In his view, although his friends did not eat and drink the whole day, they still looked fresh and comfortable doing routine work. He saw religious regularity and commitment at the highest level and spiritual sincerity amongst his Muslim friends. These, in addition to his deep interest in Islam and interaction with his Muslim colleagues, have created a profound experience that led him to accept Islam.

\section{"Pulling and Pushing Factors"}

There are always many factors that either "pull" or "push" religious conversion. Conversion amongst celebrities is no exemption. In many cases of religious conversion either among celebrities or non-celebrities, it can be found that there are some factors that encourage them to convert or some factors that pull them to convert. With this regard, it can be said that the pushing factors related to many things that are inconvenient in the old or previous religion, whereas the pulling factors related to many things that are interesting in the new religion. It is certain that push factors and pulls factors are relative things that depend on their perception toward tenets and principles of the religions.

Pulling factors in the context of religious conversion are sometimes related to doctrinal dimensions of the religion. Almost all the subjects of this study were interested in Islamic doctrine that teaches about Tawhìd (Oneness of God) in which they tended to compare it with their old religion. Some of them are interested in Islamic practice in particular daily prayer that created Muslims to be regular individuals, including about management of times.

Pushing factors are usually assumed as personal needs inherent in individual psychological dynamic, whereas pulling factors are assumed by many as social factors such as social relationships. Findings of this study will be explained from this point of view in order to construct a new interpretation that depicts the phenomena of religious conversion. Based on the findings of this study, there are three factors that influence religious conversion among celebrities. First is the need for meaning or quest for significance. This need is an absolutely 
personal thing but generally happens in all people because it is related to personal identity that exists in every person.

A quest for the meaning of life is a long journey to find the personal and social identity of human beings. In this context, religious conversion is a result of this long process. Nonetheless, it is suggested that religious conversion is not only the result of a quest for meaning but also the first step to look for the real truth assumed to exist in religion. Based on the data and information related to the subjects of the study, it can be stated that the quest for meaning is a starting point in which all subjects were pushed to explore their existences as human beings.

The quest for meaning has been identified as a fundamental human motivation by many psychological theorists. Maslow put self-actualization at the peak of his motivational hierarchy. ${ }^{48}$ In Frankl's opinion, such self-actualization is enveloped in, and gained, though some attempts to serve a cause higher than the self. Such self-transcendence can be gained only through attachment to the social group. Similarly, positive psychology has also argued that the quest for significance is central to authentic happiness that can be achieved by attaching oneself to a larger cause.

In the context of this study, it is no doubt that celebrities are a special group of people that are highlighted by the public in every detail of their life. Therefore, sometimes, they often feel lost as someone who needs private thing and situation. Those personal things even created loneliness and motivation to seek serenity from many sources, including religion. In some cases, the celebrities often find radical clerics who taught them extreme tenets and doctrines so that they transformed into odd personals in view of the public. Based on the review of the subjects' stories in many sources, those who become subjects of this research felt special experience because they converted through moderate clerics.

48 Mark Edward Koltko-Rivera, "The Worldview Assessment Instrument (WAI): The Development and Preliminary Validation of an Instrument to Assess World View Components Relevant to Counseling and Psychotherapy," Dissertation Abstracts International: Section B: The Sciences and Engineering, 2000. 
Second, Islamic narratives that spread in public attract concerns from some individuals amongst celebrities to know more about Islam and its values. These Islamic narratives spread out in many places and media so that they influence cognition and feeling of seekers of meaning within particular religious meanings. As it is well known that Islam is a religion embraced by the majority of Indonesian and, therefore, its presence in public through its follower's daily practice cannot be ignored.

Islam, as a religion of the majority, has an opportunity to be dominant culture and values in Indonesia that are easily accessible by the citizens of the country, including celebrities. Therefore, in this situation, it can be said that the presence of other people in our daily life has impacts on others through what is usually called social or friendship networks.

Third, the role of social or friendship network by celebrities is undoubtedly very pivotal. It is certain that their social networks consist of Muslim people who possess prominent religious predisposition and have strong commitment to perform their Islamic religious values, including tenets and rituals. All social psychologists argued that social influences could be denied and its pressure is more than the personal capacity to handle.

\section{Conclusion}

In short, it can be asserted that religious conversion does not happen in a vacuum. The religious conversion must be related to many factors related to personal dimensions and social dimensions of the individuals. These two personal dimensions and the social dimensions interacted each other in pushing and pulling the individuals to convert religiously and spiritually.

In some cases, personal factor triggered religious conversion (from non-Islam to Islam) among Indonesian celebrities in particular that related to the quest for meaning or loss of meaning. Nevertheless, mostly they converted to be Muslim because they have been impressed by the regular life of their colleagues in everyday life in particular when they were doing one activity in one place and in a long time. 


\section{Acknowledgment}

In the process of writing this article, I thank The Centre of Research and Publication of UIN Syarif Hidāyatullah, Jakarta, that supported this research. I also thank my research assistants, who helped me collecting references and data for this study.

\section{References}

Bandura, Albert, Gordon H. Bower, Carroll E. Izard, George A. Miller, Endel Tulving, Jerome Kagan, Eleanor E. Maccoby, et al. "Social Cognitive Theory : An Agentic Perspective." Annual Review of Psychology 55, no. 1 (2004): 1-23.

Brandt, Pierre-Yves. "Religious Conversion: A Creative Process." Archives de Psychologie (2005).

Carrothers, Robert M. "Social Typing of Religious Changers: The Impact of Motivation on the Stories of Alternators and Converts." Sociological Spectrum 27, no. 2 (March 2007): 133150.

Coates, Rodney D. "Introduction: Critical Racial and Ethnic Studies - Profiling and Reparations." American Behavioral Scientist, 47, no. 7 (2004): 873-878.

Cohen, Geoffrey Lawrence, and David Sherman. The Psychology of Change: Self-Affirmation and Social Psychological Intervention. SSRN, 2014.

Devinsky, Orrin, and George Lai. "Spirituality and Religion in Epilepsy." Epilepsy and Behavior, 2008.

Duncan, Christopher R. "Untangling Conversion: Religious Change and Identity among the Forest Tobelo of Indonesia." Ethnology 42, no. 4 (2003): 307-322.

Editors. "Sebelum Roger Danuarta, 10 Artis Ini Lebih Dulu Jadi Mualaf." JPNN.COM. Last modified 2018. msn.com/idid/hiburan/celebrity/sebelum-roger-danuarta-10-artis-inilebih-dulu-jadi-mualaf/ar-BBP93hw.

Farhadian, Charles E. Christianity, Islam and Nationalism in Indonesia. Christianity, Islam and Nationalism in Indonesia, 2005.

Garfinkel, Renee. "Personal Transformations: Moving from Violence to Peace" (2007): 1-16.

Gartrell, C David, and Zane K Shannon. “Contacts, Cognitions, 
and Conversion: A Rational Choice Approach." Review of Religious Research Religious Research Association, Inc. Review of Religious Research (1985).

Gooren, Henri. Religious Conversion and Disaffiliation: Tracing Patterns of Change in Faith Practices. Religious Conversion and Disaffiliation: Tracing Patterns of Change in Faith Practices, 2010.

K.T., Kioulos, Bergiannaki J.D., Glaros A., Vassiliadou M., Alexandri Z., and Papadimitriou G. "Religiosity Dimensions and Subjective Health Status in Greek Students." Psychiatrike= Psychiatriki (2015).

Koltko-Rivera, Mark Edward. "The Worldview Assessment Instrument (WAI): The Development and Preliminary Validation of an Instrument to Assess World View Components Relevant to Counseling and Psychotherapy." Dissertation Abstracts International: Section B: The Sciences and Engineering, 2000.

Kruglanski, Arie W., and Edward Orehek. "The Role of the Quest for Personal Significance in Motivating Terrorism." The Psychology of Social Conflict and Aggression (2011): 153-164.

Loewenthal, Kate Miriam. "Psychological Perspectives on Religion and Religiosity." Mental Health, Religion \& Culture (2015).

Lofton, Kathryn. "Religion and the American Celebrity." Social Compass, 58, no. 3 (September 2011): 346-352.

Moghaddam, Fathali M. "The Staircase to Terrorism: A Psychological Exploration." American Psychologist, 60, no. 2 (2005): 161-169.

Nasir, Haedar, and Mutohharun Jinan. "Re-Islamisation: The Conversion of Subculture from Abangan IntoSantri in Surakarta." Indonesian Journal of Islam and Muslim Societies (2018).

Nieuwkerk, Karin van. "Conversion" to Islam and the Construction of a Pious Self." The Oxford handbook of religious conversion (2014).

Paloutzian, Raymond R, James T. Richardson, and Lewis R. Rambo. "Religious Conversion and Personality Change." Journal of Personality (1999).

Palupi, Amrikh. "5 Artis Yang Telah Lebih Dahulu Mualaf Sebelum Roger Danuarta." DREAM.CO.ID. Last modified 
2018. https://www.dream.co.id/showbiz/sebelum-rogerdanuarta-5-artis-ini-memutuskan-memeluk-islam181030d.html.

Paniagua, Freddy A. "From the Terrorists' Point of View: What They Experience and Why They Come to Destroy." Journal of Homeland Security and Emergency Management 3, no. 4 (2006): 10.

Paramaditha, Intan. "Passing and Conversion Narratives: AyatAyat Cinta and Muslim Performativity in Contemporary Indonesia." Asian Cinema 21, no. 2 (2010): 69-90.

Prince, M. "The Psychology of Sudden Religious Conversion." Journal of Abnormal Psychology (1906).

Rajaei, A. R. "Religious Cognitive-Emotional Therapy: A New Form of Psychotherapy." Iranian journal of psychiatry (2010).

Rambo, Lewis R. "Conversion: Toward a Holistic Model of Religious Change." Pastoral Psychology, (1989).

Rayburn, Carole A., and Comas-Dias, Lillian. "Woman Soul: The Inner Life of Women's Spirituality Edited by Carole A. Rayburn and Lillian Comas-Diaz." American Psychological Association, 20, no. 2 (2008): 148-149.

Reinert, Duane F, and John R Bloomingdale. "Religious Experiences (Argyle 2000) PDF." International Journal for the Psychology of Religion (2000).

Seo, Myengkyo. "Falling in Love and Changing Gods: InterReligious Marriage and Religious Conversion in Java, Indonesia." Indonesia and the Malay World (2013).

Setiawan Rani, Jenny Lukito; Dwisaptani. "Konversi Agama Dalam Kehidupan Pernikahan." Jurnal Humaniora (2008).

Shaver, Kelly G. "Principles of Social Psychology." Principles of Social Psychology (1987).

Shihab, MQ. "Membumikan Al-Quran: Fungsi Dan Peran Wahyu Dalam Kehidupan Masyarakat." Bandung: Mizan (1992).

Slavkova, M. "Gypsies in Lom: The Case of the Gypsies Who Convert to Protestant Christianity." In Religious Conversion After Socialism, 2005.

Steger, MF, S Oishi, and S Kesebir. "Is a Life without Meaning Satisfying? The Moderating Role of the Search for Meaning in Satisfaction with Life Judgements." The Journal of Positive 
Psychology 6, no. 3 (2011): 173-180.

Ullman, Chana. "The Transformed Self: The Psychology of Religious Conversion." The Transformed Self: The Psychology of Religious Conversion., 1989.

\section{Internets and Social Media Sources}

https://feed.merdeka.com/story/perjalanan-spiritual-dian-sastromemilih-memeluk-agama-islam-170605j.html

https://id.wikipedia.org/wiki/Alice_Norin

https://id.wikipedia.org/wiki/Chicha_Koeswoyo https://id.wikipedia.org/wiki/Pasir_Berbisik

https://m.merdeka.com/piala-dunia/calon-istri-fachri-albar-renata-

kusmanto-sudah-mualaf.html

https://swararakyat.com/sedih-kisah-mualaf-chicha-koeswoyomamaku-perempuan-luar-biasa/

https://www.liputan6.com/showbiz/read/2271457/mualaf-renata-

kusmanto-belajar-agama-dengan-mertua

https://www.matamata.com/seleb/2018/07/10/083304/7-artisdengan-kecerdasan-luar-biasa.

https://www.tabloidbintang.com/berita/polah/read/23859/ini-

cerita-renata-kusmanto-nikmati-bulan-ramadhan-kedua https://www.viva.co.id/showbiz/gosip/1107702-bikin-haru-roger-

danuarta-beberkan-alasannya-masuk-islam.

https://www.viva.co.id/siapa/read/908-chicha-koeswoyo

https://www.viva.co.id/siapa/read/981-roger-danuarta

https://www.youtube.com/watch?v=3vIQj3rD4y8

https://www.youtube.com/watch?v=9AbC_RihnpY

https://www.youtube.com/watch?v=LAFbccty36E

https://www.youtube.com/watch?v=r2cY0RW4Nu4

https://www.youtube.com/watch?v=TfXjgOXx3IQ

https://www.youtube.com/watch?v=Ttv2ngXycuc 